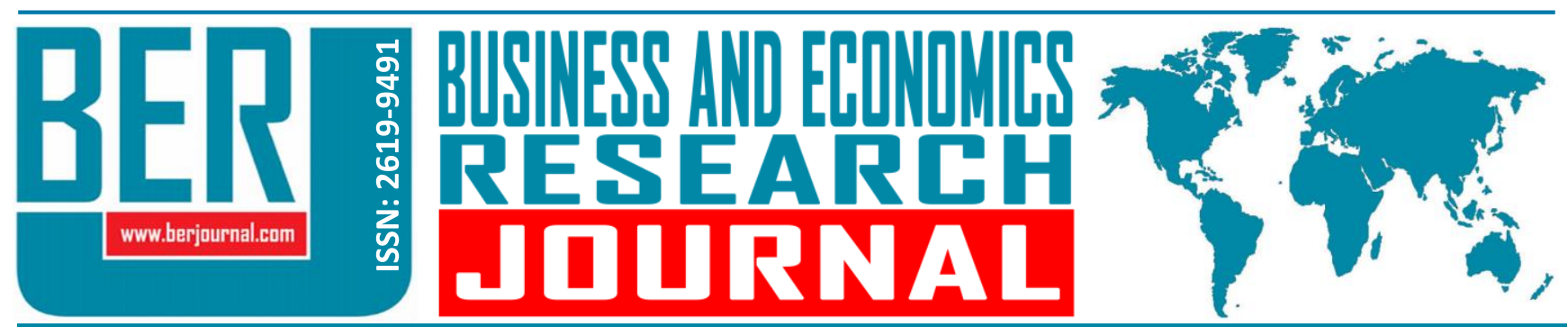

Business and Economics Research Journal Vol. 9, No. 3, 2018, pp. 697-713 doi: 10.20409/berj.2018.132

\section{Üniversite Öğrencilerinin Emoji Kullanımları ve Emoji Kullanan Markalara Karşı Tutumları Üzerine Bir Araştırma}

\author{
Ramazan Kurtoglua Tugba Ozboluk $^{\mathrm{b}}$
}

Öz: Sözsüz iletişim unsurlarının yerine kullanılması anlamında dijital iletişimde önemli bir boşluğu doldurduğu düşünülen emojilerin markaya yönelik tutuma ve ağızdan ağıza iletişime etkisinin olup olmadığı sorusu, bu araştırmanın çıkış noktasını oluşturmaktadır. Araştırmanın amacı, hem öğrencilerin genel olarak hem de cinsiyete göre ayrı ayrı, emoji kullanım durumlarının, emoji kullanan markalara yönelik tutumlarını ve bu tutumlarının da, emoji kullanan markalar hakkındaki pozitif ağızdan ağıza iletişimlerini etkileyip etkilemediğini belirlemektir. Üniversite öğrencilerinden anket yöntemiyle veri toplanmıs ve toplanan veriler yapısal eşitlik modellemesi kullanılarak analiz edilmiştir. Araştırma sonucuna göre, hem öğrencilerin genel olarak hem de cinsiyete göre ayrı ayrı emoji kullanımlarının emoji kullanan markalara yönelik tutumları üzerinde istatistiksel açıdan anlamlı ve pozitif yönlü bir etkiye sahip olduğu, emoji kullanan markalara yönelik tutumlarının da emoji kullanan markalar hakkındaki pozitif ağızdan ağıza iletişimleri üzerinde anlamlı ve pozitif yönlü bir etkiye sahip olduğu sonucuna ulaşılmıştır. Bunun yanında, belirtilen etkilerin istatistiki olarak cinsiyete göre anlamlı bir farklılık göstermediği de tespit edilmiștir.

\section{An Investigation on University Students' Emoji Usage and Their Attitudes Toward Brands Using Emoji}

Abstract: The question whether the emoji that is considered to fill an important gap in digital communication by being used as a nonverbal communication cue, has an effect on the attitudes toward brands and word of mouth communication is the main starting point of this research. Aim of this study is to determine whether the emoji usage of university students (both generally and according to gender) affect their attitude toward the brands using emoji, and if this attitude affect their positive word of mouth communication about these brands. Data were collected from university students by a questionnaire and analyzed by using structural equation modeling. The results show that emoji usage of students (both generally and according to gender) has a statistically significant and positive effect on the attitudes toward brands using emoji, and these attitudes have positive and significant effects on their positive word of mouth communication. Besides this, it was also found that the aforementioned effects did not show a statistically significant difference according to gender.
Anahtar Sözcükler: Emoji, Emoji Kullanımı, Markaya Yönelik Tutum, Pozitif Ağızdan Ağıza İletişim, Yapısal Eşitlik Modeli

JEL: M30, M31

$\begin{array}{ll}\text { Geliş } & : \text { 30 Mart } 2018 \\ \text { Düzeltme } & : \text { 15 Mayıs 2018 } \\ & \text { 20 Haziran } 2018 \\ \text { Kabul } & : 25 \text { Haziran } 2018 \\ \text { Tür } & : \text { Araştırma }\end{array}$

Keywords: Emoji, Emoji Usage, Attitude Toward Brand, Positive Word of Mouth, Structural Equation Model

JEL: M30, M31

Received : 30 March 2018

Revised : 15 May 2018

20 June 2018

Accepted : 25 June 2018

Type : Research

a Asst. Prof., PhD., Bozok University, Faculty of Economics and Administrative Sciences, Yozgat, Turkiye, kurtoglu38@gmail.com (ORCID ID: 0000-0001-7899-9625)

b Asst. Prof., PhD., Bozok University, Faculty of Economics and Administrative Sciences, Yozgat, Turkiye, tozboluk@gmail.com (ORCID ID: 0000-0003-4647-8870) 


\section{Giriş}

Dijital çağda görsellerin artan gücü, iletişimde görsel bir dilin önlenemez yükselişini de beraberinde getirmiştir. Her gün karşılaştı̆̆ımız videolar, anlık fotoğraf paylaşımları (snap), mizah içerikli kesyap çalışmaları (caps), fotoğraflar, bilgi grafikleri (infografik) ile gündelik hayatın ve sosyal medya uygulamalarının merkezinde yer alan görseller, iletişimi giderek, işaretler semboller ve ikonlardan oluşan bir iletişime dönüştürmüştür. Giderek artan sosyal medya kullanımı istediğimiz her şeyi özellikle de görsel içerikleri anında paylaşabilme imkânı sağlamaktadır. Görsel içeriklerin karşı tarafa duyguyu aktarmada metinsel içeriklere göre daha başarılı olması (Yakın ve Eru, 2017:239; Buehner ve Sommerfeldt, 2013:2) özellikle bu tür paylaşımların niceliğini de giderek artırmaktadır.

Tüketicilerin gündelik hayatta çok fazla pazarlama mesajına maruz kaldığı bir çağda görsel iletişim, pazarlamacıların tam olarak intiyaç duydukları bir iletişim biçimi olarak karşımıza çıkmaktadır. Görsel iletişimin bir parçası olan emojinin akıllı telefon kullanan tüketiciler tarafından yaygın olarak kullanılması, internetin ve sosyal medyanın hayatımıza yeni bir okuryazarlık deneyimi katması sonucunu doğurmuştur. Farklı dilleri konuşan insanları ortak bir paydada birleştirebilecek olan emoji vb. görsel içerikler, pazarlama uygulayıcılarının sosyal medyada kullanılan dili daha doğru anlayabilmeleri açısından önem arz etmektedir. Literatürde emojinin yeni bir dil mi ortaya çıkardığı, yoksa popüler kültürün gelip geçici bir modası mı olduğu halen tartışıırken, markaların pazarlama iletişimlerinde giderek artan bir oranda emoji kullanmaları, hem teorisyenler hem de uygulamacılar açısından önemli çıkarımlara sahiptir. Bu açıdan bu çalışmada öğrencilerin emoji kullanım durumlarının, emoji kullanan markalara yönelik tutumlarını ve bu tutumlarının da, emoji kullanan markalar hakkındaki pozitif ağızdan ağıza iletişimlerini etkileyip etkilemediğini belirlemek amaçlanmıştır.

\section{Kavramsal Çerçeve}

\subsection{Emoji Kavramı ve Markaların Emoji Kullanımı}

Görsel içerik özellikle Instagram ve Vine gibi görseller etrafında şekillendirilen sosyal medya platformlarında, Facebook, Twitter, Tumblr gibi hem metin hem görsel içeren bir forma sahip platformlarda ve bilginin sunumunun ve sağlanmasının önem arz ettiği görsel uygulamalar ve profillerde kritik öneme sahip bir bileşen olarak görülmektedir (Highfield ve Leaver, 2016:47).

Görsellerin duygu aktarmada ve alıcıyı çekmede metinlerden daha etkili bir iletişim kurabilme yeteneğine sahip olmasına (Buehner ve Sommerfeldt, 2013:2) ve görsel iletişimin giderek artmasına bağı olarak ortaya çıkan emojiler (Danesi, 2017:182), dijital iletişimde önemli bir boşluğu doldurmaktadır. Metin tabanlı iletişim kurulurken, yüz ifadeleri ve beden dili gibi sözsüz iletişim ipuçlarının olmaması konuşmacılar için duyguların ifade edilmesini zorlaştırmaktadır (Walther ve D’Addario, 2001:325). Ağırlıklı olarak metin tabanlı iletişime dayanan bilgisayar aracılı iletişimde sözsüz iletişim unsurlarının yokluğu ise, duygusal ifadelerin abartılmasına ya da hafife alınmasına ve bu nedenle de uygun olmayan tepkilerin ortaya çıkmasına neden olabilmektedir (Derks, vd., 2008:776). Bu bağlamda emoji, metin tabanlı iletişimde kullanıldığında söylenenlerin anlaşılmasını kolaylaştırması açısından sözsüz iletişim unsurlarına benzetilmektedir (Cohn, 2015).

Duygu ikonları ve emojiler gibi görseller standart dilin yerine kısmen geçebilecek bir dil (Danesi, 2017:177) olarak görülmekle birlikte, duyguları ifade etmenin çabasız ve otomatik bir yolu olarak da düşünülmektedir (Cowie vd., 2001:48). Bu semboller, bilgisayar aracılı iletişimde duyguları ya da ruh hallerini iletmeye yardım etmek amacıyla geliştirilmiş yüz ifadelerinin ya da jestlerin soyutlaşmış halidir (Walther ve D’Addario, 2001:324). Emoji kısaca "metin tabanlı mesajlarda, e-postalarda ve sosyal medya platformlarında kullanılan dijital resimli diyagramlar" olarak tanımlanmaktadır (Stark ve Crawford, 2015:1). Japonca'da emoji, bir duygu, fikir, durum ya da olayın görsel bir sunumu anlamına gelmektedir (Gaffey, 2015). illk olarak 1990'da Japonya'da ortaya çıkan emojiler, resmi olarak 2009'a kadar Unicode Standartlarına eklenmemiştir (Davis ve Edberg, 2015:4). Unicode Standartlarına göre her yıl değişen emoji sembollerini ve anlamlarını belgeleyen Emojipedia'ya göre resmi olarak Temmuz 2017 itibariyle insan ve gülen yüz, hayvan ve doğa, yiyecek içecek, 
seyahat ve mekan, nesne, sembol ve bayrak kategorilerinde yer almak üzere toplam 2623 adet emoji mevcuttur (https://emojipedia.org/emoji-5.0/).

Emojiler ya da duygu ikonları, neredeyse bütün sosyal medya kanallarına ve anlık mesajlaşma platformlarına nüfuz eden küresel bir iletişim aracı haline gelmiştir (Park vd., 2014). Instagram'da paylaşılan metinlerin neredeyse yarısı emoji içermektedir (Dimson, 2015). Online dünya nüfusunun \% 92'si tarafından kullanılan emojiler, dil sınırlarını ortadan kaldırarak iletişim kurmayı kolaylaştırmaktadır. Bu açıdan emoji, bütün dünyada en hızı büyüyen dil olarak görülmektedir (Emoji Report, 2016).

Küresel beyin teorisine (Bloom, 2000) göre, bilginin herhangi bir kişi, kurum veya sistemde merkezileştirilmediği, tüm dünyayı birbirine bağlayan sinir sistemi gibi işlev gören, internet üzerinden ortaya çıkan tek bir bilgi öğrenme-iletişim sistemi ortaya çıkmıştır. Emojinin bu küresel beyin evreni için mükemmel bir dil oluşturduğu düşünülmektedir. Ancak, her ne kadar emojinin küresel bir dil olabileceği düşünülse de, yeni teknolojiler ve yeni intiyaçlar ortaya çıktıkça geçici bir olgu olarak geride kalabilmesi de intimal dâhilinde görülmektedir. Bu açıdan emoji, kolay kullanımı ve çoğu küresel semantik karakteri nedeniyle geçici bir dil olarak da yorumlanmaktadır (Danesi, 2017:177). Emojinin dünyanın her yerinde akıllı telefon kullanan herkes tarafından anlaşılabilmesi ise, küresel markaların emoji kullanımına olan ilgisinin de artmasını sağlamıştır (Kurtoğlu ve Özbölük, 2016:149). Emojiler markaların gündelik iletişiminde, reklamlarında, ikna kampanyalarında ve diğer birçok yaratıcı iletişim türünde aktif olarak kullanılmaktadır. Hatta bazı işletmeler daha da ileri giderek kendi emojilerini yaratmışlardır (Lu vd., 2016:770). Emoji içeren diyalogların, marka çağrışımı, ürün ve marka farkındalığı ortaya çıkarabileceği ileri sürülmektedir (Emoji Report, 2016).

Emojilerin pazarlamadaki etkinliğini ölçmek amacıyla yaptıkları çalışmalarında Yakın ve Eru (2017) kâr amacı gütmeyen işletmelerin de dâhil olduğu birçok işletmenin emojiyi bir tutundurma aracı olarak reklam kampanyalarında kullandığını ve emojilerin özellikle sosyal medya reklamlarında daha etkili olduğunu bulmuşlardır. Çalışmada ayrıca öğrenciler emojilerle yapılan reklam kampanyalarını daha yaratıcı ve inovatif bulduklarını ifade etmişlerdir (Yakın ve Eru 2017:238). Gökaliler ve Saatçioğlu (2016) emoji içerikli reklamlara yönelik tüketicilerin tutumlarını belirlemek amacıyla yaptıkları çalışmalarında, tüketicilerin emoji kullanımları arttığında, emoji içerikli reklamlara yönelik tutumlarının da olumlu yönde arttığını bulmuşlardır. Ayrıca tüketicilerin emoji kullanım sıklığı arttıkça emoji içerikli reklamlara yönelik dikkati de artmaktadır (Gökaliler ve Saatçioğlu 2016:85). Görsel içeriğin kelimelerden daha büyük bir duygusal etki yarattığı düşünüldüğünde, işletmelerin reklam kampanyalarında emoji kullanmalarının faydaları da daha iyi anlaşılış olacaktır (Yakın ve Eru, 2017:239).

Emojilerin ya da duygu ikonlarının cinsiyetle ilişkisini araştıran çalışmalara bakıldığında ise çok sınırlı sayıda araştırmaya rastlanmıştır. Hwang (2014) duygu ikonu kullanma motivasyonlarının cinsiyete göre farklılaştığını ve mobil mesajlaşmalarda kız öğrencilerin erkek öğrencilere oranla duygularını ve samimiyetlerini ifade etmede daha fazla duygu ikonu kullanma eğiliminde olduğunu bulmuştur. Lee (2003) internet üzerinde yalnız kadın, yalnız erkek ya da her ikisinin birlikte yer aldığı bir grup olması fark etmeksizin kadınların erkeklere oranla daha fazla duygu ikonu kullandığını bulmuşlardır. Wolf (2000:827) ise tek bir cinsiyetten ziyade kadın ve erkeklerin birlikte yer aldığı çevrimiçi haber gruplarında erkeklerin daha fazla duygu ikonu kullanarak duyguları ifade etmede kadın standartlarını benimsediğini bulmuşlardır.

\subsection{Pozitif Ağızdan Ağıza İletişim}

Tüketicilerin gün içinde çok fazla bilgi ve mesaja maruz kalmaları, bunlar üzerine düşünecek ve inceleme yapacak zamanı bulamamalarına neden olmaktadır (Silverman, 2001:9). Tüketiciler, satın alma kararı verirken ek alternatifleri veya fazladan ürün niteliklerini elimine etmek için diğer tüketicilerin görüşlerinden yararlanırlar (Duhan vd., 1997:287). Tüketiciler ayrıca, ürün ve hizmet satın almadan önce kendilerini daha rahat hissetmek için de bilgi arayışı içindedirler (Pitta ve Fowler, 2005:283). Tüketicilerin satın alma öncesinde seçeneklerini azaltmak ya da diğer tüketicilerin görüşlerinden yararlanarak daha fazla bilgiye ulaşmak istemeleri, ağızdan ağıza iletişim kavramını ortaya çıkarmıştır.

Tüketiciler satın alma öncesinde aktif bir şekilde ağızdan ağıza iletişim yoluyla bilgi arayışına gitmektedirler (Mangold vd., 1999:73). Ağızdan ağıza iletişim, "göndericinin pazardan bağımsız olduğu 
tüketici yönlü pazarlama iletişimi kanalı” (Brown, Broderick ve Lee, 2007:4) olarak tanımlanmaktadır. Ağızdan ağıza iletişim kısaca, iki ya da daha fazla kişi arasında, ürün, markalar veya hizmetler hakkında ticari kaygı gütmeden karşılıklı fikir alışverişinin gerçekleştiği bir iletişim türüdür (Lam ve Mizerski, 2005:217). Ağızdan ağıza iletişim kavramı ilk olarak Arndt (1967:190) tarafından "bir ürün, marka veya hizmet hakkında, bir alıcı ve kaynak arasında gerçekleşen, ticari olmayan, yüz yüze iletişim" olarak tanımlanmaktadır. Ağızdan ağıza iletişim, aile veya yakın çevreden oluşan bağımsız bireyler arasındaki olumlu veya olumsuz sözel iletişim biçimidir (Ennew vd., 2000:77). Bu bağlamda Stokes ve Lomax (2002:350), alıcının kaynağı tarafsız olarak gördüğü tüm kişilerarası iletişimleri ağızdan ağıza iletişim olarak tanımlamaktadır.

Sernovitz (2006) ise ağızdan ağıza iletişimi bir tür tüketiciden tüketiciye (CtoC) pazarlama olarak görmektedir. Ticari olmayan doğası gereği ağızdan ağıza iletişim işletmeler tarafından yürütülen diğer tutundurma çabalarına kıyasla tüketiciler tarafından daha az şüpheyle takip edilmektedir (Gremler vd., 2001: 44). İşletmelerin gerçekleştirdiği iletişim çabalarına nazaran daha güvenilir ve inandırıcı olarak algılanması (Schiffman ve Kanuk, 1995; Silverman, 2001:9), ağızdan ağıza iletişimin tüketicilerin bilgi aramasında daha önemli bir rol oynamasını sağlamaktadır.

Kaynağın ürün, marka ya da hizmetle ilgili olumlu ya da olumsuz deneyimlerini alıcıya aktararak duyduğu tatmini ya da tatminsizliği paylaşması bakımından ağızdan ağıza iletişim pozitif, negatif, ya da nötr olabilmektedir (Anderson, 1998:6). Ağızdan ağıza iletişim, işletmelerin ürünlerini tutundurmaları için değerli bir araç olarak kabul edilmektedir. Özellikle tatmin düzeyi yüksek olan tüketicilerin pozitif ağızdan ağıza iletişime daha yatkın oldukları gözlenmiştir (Naylor ve Kleiser, 2000:27).

Tüketicilerin pozitif ağızdan ağıza iletişimi yaymalarının nedeni aslında o işletmeye yardım etmek istemeleridir. Bir işletmeye yönelik tüketim deneyimlerinden aşırı memnun olan tüketiciler bu işletme ile ilgili başkalarına pozitif mesajlar yayarak o işletmeye yardımcı olurlar (Sundaram vd., 1998:530). Pozitif ağızdan ağıza iletişim işletme ve marka hakkında olumlu imaj yaratabilmekte (Arndt, 1967), bu nedenle pazarlamacıların işletme için pozitif ağızdan ağıza iletişime olanak sağlayan bir çevre yaratmaları oldukça önem arz etmektedir (Sundaram vd., 1998:531).

Harris ve Prideaux (2017:376) sürekli değişen dinamik bir ortam olan internette ağızdan ağıza iletişimde mesajın sadece yazılı olarak değil, Skype gibi sözlü ifadelerle, resimler ve emojiler gibi görsel ifadelerle ya da hepsinin bir birleşimi halinde sunulabileceğini belirterek, teknolojinin iletişimde meydana getirdiği değişimin araştırılmasının önemine vurgu yapmıştır. Ancak literatürde emoji kullanımı ve ağızdan ağıza iletişimin ilişkisini araştıran çok az çalışmaya rastlanılmaktadır. Derks vd. (2007:848), duygu ikonlarının internetteki sosyal etkileşim üzerindeki etkilerini araştırdıkları çalışmalarında, negatif mesajlardan ziyade pozitif mesajlarda daha fazla duygu ikonu kullanıldığını bulmuşlardır.

Qiu vd. (2016:12) ise duygu ikonlarının ağızdan ağıza iletişime etkisini araştırdıkları çalışmalarında, duygu ikonlarının alııı üzerinde mesajın kaynağına karşı duyulan empatiyi artırdığını ve artan empatinin, alıcının algılanan güvenilirliğini ve mesajın algılanan kalitesini artırarak ağızdan ağıza iletişimle gönderilen mesajın ikna edilirliğini de artırdığını bulmuşlardır. Emojilerin ve duygu ikonlarının çevrimiçi tüketici yorumları, algılanan işletme kalitesi ve satın alma niyetiyle ilişkisinin araştırıldığı bir başka çalışmada ise Hill (2016:37), çoğu durumda mesajlara eklenen olumlu emojilerin işletmelere ilişkin algılanan kaliteyi ve satın alma niyetini olumlu etkilediğini bulmuştur.

\subsection{Markaya Yönelik Tutum}

Tüketici temelli marka değerini oluşturan boyutlardan biri olarak ele alınan markaya yönelik tutum (Feldwick,1996), kişinin markaya ilişkin içsel bir değerlendirmesi olarak tanımlanmaktadır (Mitchell ve Olson, 1981:320). Keller (1993:18) markaya yönelik tutumun, markanın sağladığı yararların ve niteliklerin bir bileşkesi olduğunu ileri sürmüştür. Agarwal ve Malhotra (2005:483)'ya göre markaya yönelik tutum, tüketicilerin belirli bir markaya ilişkin inançlarına dayanan genel yargılarıdır. Phelps ve Hoy (1996:84) ise markaya yönelik tutumu, bireye bir reklam izletildikten sonra belirli bir markaya yönelik olumlu ya da olumsuz bir tavır alma eğilimi olarak tanımlamaktadır. 
Basitçe, tüketicinin markayı genel olarak değerlendirmesi (Öztürk ve Savaş, 2014:6124) olarak açıklanabilen markaya yönelik tutum, kişinin markayı sevmesi, hoşlanması ya da hoşlanmamasının derecesini ifade etmektedir (Kaya ve Marangoz, 2014:488). Spears ve Singh (2004:55) markaya yönelik tutumun, markaya yönelik hislerden farklı olduğunu, hislerin geçici olduğunu, tutumların ise hislere göre daha kalıcı olduğunu belirtmişler ve markaya yönelik tutumu "markanın davranışı ortaya çıkaran görece daha kalıcı, tek boyutlu özet bir değerlendirmesi" olarak tanımlamışlardır.

Markaya yönelik tutumun hem markaya yönelik iletişimde hem de satın alma niyeti ve davranışında belirleyici nitelikte olması (Uztuğ, 2003:33), konunun araştırılmasının pazarlama literatürü açısından önemli olduğunu göstermektedir. Satın alma niyeti üzerinde pozitif bir etkisi olduğu görülen (Kotler ve Keller, 2008; Hwang vd., 2011:897) ve satın alma davranışının öncüllerinden biri olarak yorumlanan markaya yönelik tutumun (Kaya ve Marangoz,2014:488) ağızdan ağıza iletişime etkisiyle ilgili çalışmalara baktığımızda ise genelde ağızdan ağıza iletişimin tüketicinin markaya yönelik tutumunun belirlenmesinde önemli bir rolü olduğu görülmektedir.

Swanson ve Kelley (2001:207) tek başına pozitif ağızdan ağıza iletişimin markaya yönelik olumlu tutum oluşturabileceğini ileri sürmüştür. Wu ve Wang (2010:448) ise elektronik ağızdan ağıza iletişimde mesaj çekiciliğinin ve kaynak güvenilirliğinin markaya yönelik tutum üzerindeki etkisini araştırdıkları çalışmalarında mesaj kaynağının güvenirliğinin yüksek olduğu durumlarda pozitif ağızdan ağıza iletişimin daha iyi bir marka tutumuna yol açtığını bulmuşlardır.

\section{Tasarım ve Yöntem}

Nedensel tasarıma sahip bu araştırma, uygulamalı araştırma kategorisinde değerlendirilebilir. Araştırmanın yöntemi ile ilgili açıklamalar aşağıda başlıklar halinde yapıımıştır.

\subsection{Araştırmanın Amacı ve Kapsamı}

$\mathrm{Bu}$ araştırmanın amacı, üniversite öğrencilerinin emoji kullanım durumlarının, emoji kullanan markalara yönelik tutumlarını ve bu tutumlarının da, emoji kullanan markalar hakkındaki pozitif ağızdan ağıza iletişimlerini etkileyip etkilemediğini belirlemektir.

Öğrencilerin değerlendirmeleri cinsiyete göre farklılık gösterebilir. Nitekim literatürde benzer konularda yapılan bazı çalışmalarda (Hwang, 2014; Lee, 2003; Wolf 2000) cinsiyet açısından farklılıklar incelenmiştir. Bu doğrultuda bu araştırma da yukarıda belirtilen etkilerin cinsiyet açısından farklılaşıp farklılaşmadığının incelenmesi araştırmanın alt amacı olarak belirlenmiştir.

Araştırma kapsamına Bozok Üniversitesi, İktisadi ve İdari Bilimler Fakültesi'nde normal ve ikinci öğretim kapsamında öğrenim gören öğrenciler dahil edilmiştir. Bu kapsamda öğrencilerin emoji kullanım durumları, emoji kullanan markalara yönelik tutumları ve emoji kullanan markalar hakkındaki pozitif ağızdan ağıza iletişim durumları incelenmiştir. Araştırma kapsamının bu şekilde belirlenmesinin nedenleri arasında, emoji kullanımının güncel ve özellikle gençler arasında gittikçe yaygınlaşan bir konu olması, zaman ve ulaşılabilirlik kısıtları nedeniyle daha kolay ve hızlı veri toplanabilecek olması, incelenen konunun (emoji kullanımı) daha çok gençlere hitap ettiği düşüncesi yer almaktadır. Emojilerin duygu ve düşünceleri kısa yoldan ve hızlı bir biçimde ifade edebilme ihtiyacı doğrultusunda özellikle $Z$ kuşağı tarafından daha yoğun bir şekilde kullanılması (Kurtoğlu ve Özbölük, 2016:147) örneklem seçiminde üniversite öğrencilerinin tercih edilmesinde belirleyici olmuştur.

\subsection{Araştırmanın Modeli ve Hipotezler}

Araştırmanın modeli aşağıdaki gibidir (Şekil 1.) 
Şekil 1. Araştırmanın Modeli

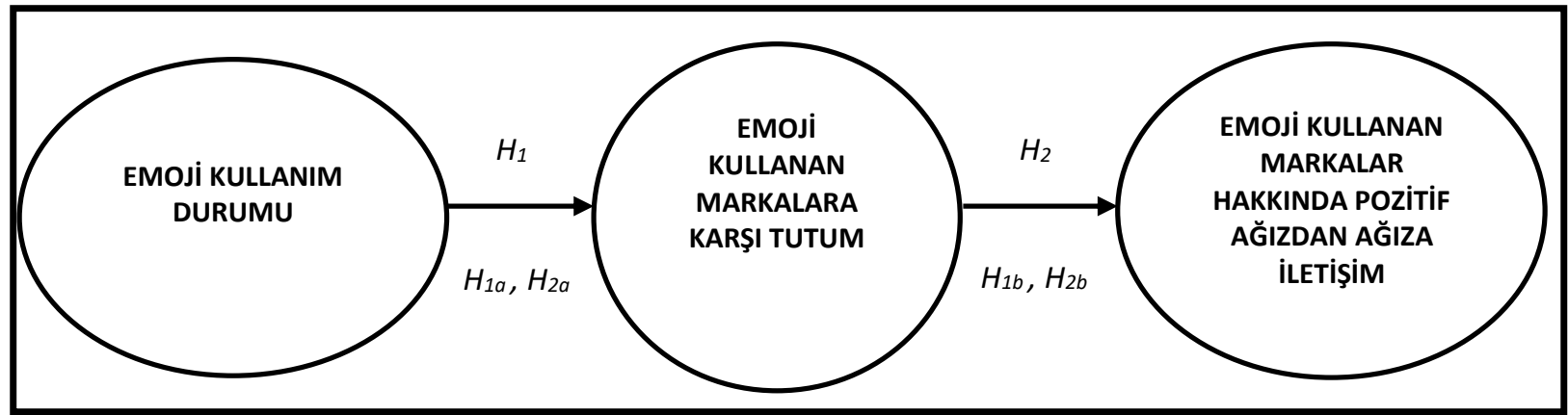

Araştırma modeline göre, öğrencilerin hem genel olarak hem de cinsiyete göre ayrı ayrı, emoji kullanım durumlarının emoji kullanan markalara karşı tutumlarını ve emoji kullanan markalara karşı olan tutumlarının da, emoji kullanan markalar hakkındaki pozitif ağızdan ağıza iletişimi etkileyip etkilemediği test edilmektedir.

Araştırma modeli ve yukarıda yapılan açıklamalar ışığında araştırma hipotezleri de şu şekilde oluşturulmuştur:

$\mathrm{H}_{1}$ : Öğrencilerin emoji kullanım durumu, emoji kullanan markalara karşı olan tutumlarını anlamlı ve pozitif yönde etkiler.

$\mathrm{H}_{1 \mathrm{a}}$ : Kız öğrencilerin emoji kullanım durumu, emoji kullanan markalara karşı olan tutumlarını anlamlı ve pozitif yönde etkiler.

$\mathrm{H}_{1 b}$ : Erkek öğrencilerin emoji kullanım durumu, emoji kullanan markalara karşı olan tutumlarını anlamlı ve pozitif yönde etkiler.

$\mathrm{H}_{2}$ : Öğrencilerin emoji kullanan markalara karşı olan tutumları, emoji kullanan markalar hakkındaki pozitif ağızdan ağıza iletişimi anlamlı ve pozitif yönde etkiler.

$\mathrm{H}_{2 \mathrm{a}}$ : Kız öğrencilerin emoji kullanan markalara karşı olan tutumları, emoji kullanan markalar hakkındaki pozitif ağızdan ağıza iletişimi anlamlı ve pozitif yönde etkiler.

$\mathrm{H}_{2 b}$ : Erkek öğrencilerin emoji kullanan markalara karşı olan tutumları, emoji kullanan markalar hakkındaki pozitif ağızdan ağıza iletişimi anlamlı ve pozitif yönde etkiler.

Araştırmada kullanılan emoji kullanım durumu, emoji kullanan markalara karşı olan tutum ve emoji kullanan markalar hakkındaki pozitif ağızdan ağıza iletişim ölçeklerinde yer alan ifadelerin açıklığını ve anlaşılır olup olmadığını tespit etmek amacıyla ön test ve uzman görüşlerine başvurulmuş, gerekli düzeltmeler yapıldıktan sonra anketler uygulanmıştır.

Araştırma kapsamında toplanan verilerin analizi için çeşitli istatistik paket programlarından yararlanılmıştır. Elde edilen veri setinin analize uygun hale gelebilmesi için, veriler ön incelemeden geçirilmiş ve analize uygun olmayan veriler veri setinden çıkarılmıştır.

\subsection{Anket Formu ve Ölçekler}

Araştırmanın anket formu iki bölümden oluşmaktadır. Illk bölümde, 7'li Likert ölçeğine göre düzenlenmiş (1=Kesinlikle Katılmıyorum, 7=Kesinlikle Katılıyorum), öğrencilerin emoji kullanım durumları, emoji kullanan markalara karşı olan tutumları ve emoji kullanan markalar hakkındaki pozitif ağızdan ağıza iletişimlerini ölçmeye yönelik ölçekler yer almaktadır. İkinci bölümde ise öğrencilerin demografik özelliklerine (yaş, cinsiyet, harcama vb.) yönelik sorular yer almaktadır.

Araştırmada, literatürde yer alan ve daha önce başka araştırmacılar tarafından geliştirilen ölçeklerden yararlanılmıştır. Ölçeklerde yer alan ifadelerde bazı uyarlamalar yapılmıştır. Emoji kullanım durumu ölçeği, 
Gökaliler ve Saatçioğlu (2016) ve Lee (2017)'nin çalışmalarından, emoji kullanan markalara karşı tutum ölçeği Spears ve Singh (2004)'in çalışmasından ve emoji kullanan markalar hakkındaki pozitif ağızdan ağıza iletişim ölçeği ise Gremler ve Gwinner (2000)'in çalışmasından faydalanılarak geliştirilmiştir.

\subsection{Ana Kütle ve Örneklem}

Araştırmanın ana kütlesi, Bozok Üniversitesi Iktisadi ve İdari Bilimler Fakültesinde okuyan 1376 öğrenciden oluşmaktadır. Bu ana kütle büyüklüğünde \%95 güven sınırında örnek hacmi 278 olarak belirlenmiştir (Kurtuluş, 1998: 236). Bazı anketlerin boş bırakılabileceği veya hatalı doldurulabileceği düşünülerek toplamda 320 adet anket formu dağıtılmıştır. Bunlardan 310 anket formu geri toplanabilmiş, 18 adet anketin hatalı ve yanlış doldurulduğu tespit edilerek değerlendirme dışı bırakılmıştır. Böylece değerlendirmeye alınan anket formu sayısı 292 olmuştur. Öğrencilerin okudukları bölümler, sınıflar ve öğretim türü dikkate alınarak kota örneklemesi yöntemiyle katılımcılar belirlenmiştir. Anketler Nisan-Mayıs 2017 tarihleri arasında, dağıt-topla yöntemi kullanılarak uygulanmıştır.

\subsection{Normallik, Güvenilirlik ve Geçerlilik Analizleri}

Verilerin normalliğini test etmek için çarpıklık ve basıklık değerleri kullanılabilmektedir (Tabachnick ve Fidell, 2012: 79). Araştırmada kullanılan değişkenlerin çok değişkenli normal dağılıma uygunluğunu test etmek için, her bir değişkenin çarpıklık ve basıklık değerleri hesaplanmıştır (Tablo 1). Hesaplanan çarpıklık ve basıklık değerleri, (K7 değişkeni basıklık değeri 3'ün biraz üzerinde olmak üzere) literatürde tavsiye edilen \pm 3 (bazı yazarlara göre \pm 2 ) değerleri (Garson, 2012:18-19; Kalaycı, 2006: 6 ve 209) arasında kaldığı için değişkenlerin normal dağılıma uyduğu söylenebilir.

Ölçeklerin içsel tutarlılı̆ını değerlendirmek için, güvenilirlik analizi yapılarak, Cronbach's Alpha değerleri hesaplanmış (Tablo 1) ve tüm ölçeklerde $\alpha$ değerinin, Hair vd. (2005) tarafından tavsiye edilen 0,70 değerinin üstünde olduğu tespit edilmiştir (Hair vd, 2005:137). Buna göre ölçeklerin güvenilir olduğu sonucuna varılmıştır.

Tablo 1. Değişkenlerin Çarpıklık, Basıklık ve Ölçeklerin Cronbach's Alpha Değerleri

\begin{tabular}{|c|c|c|c|c|}
\hline Ölçekler & Değişkenler & Çarpıklık & Basıklık & Cronbach's Alpha \\
\hline \multirow{4}{*}{$\begin{array}{l}\text { Emoji Kullanan Markalar Hakkındaki Pozitif } \\
\text { Ağızdan Ağıza İletişim (EKMHWOMC) }\end{array}$} & W1 & ,136 & $-1,173$ & \multirow{4}{*}{0,920} \\
\hline & W2 & ,273 & $-1,148$ & \\
\hline & W3 & ,316 & $-1,142$ & \\
\hline & W4 & ,782 &,- 522 & \\
\hline \multirow{5}{*}{ Emoji Kullanan Markalara Karşı Tutum (EKMKT) } & T1 &,- 807 &,- 073 & \multirow{5}{*}{0,864} \\
\hline & $\mathrm{T} 2$ &,- 299 &,- 968 & \\
\hline & T3 &,- 601 &,- 539 & \\
\hline & T4 &,- 767 &,- 206 & \\
\hline & T5 &,- 813 &,- 136 & \\
\hline \multirow{8}{*}{ Emoji Kullanım Durumu (EKD) } & K1 & $-1,690$ & 2,961 & \multirow{8}{*}{0,878} \\
\hline & K2 & $-1,421$ & 1,641 & \\
\hline & K3 & $-1,435$ & 2,274 & \\
\hline & K4 &,- 518 &,- 791 & \\
\hline & K5 & $-1,405$ & 2,113 & \\
\hline & K6 & $-1,234$ & 1,599 & \\
\hline & K7 & $-1,464$ & 3,438 & \\
\hline & K8 &,- 942 & ,130 & \\
\hline
\end{tabular}

Çalışmada oluşturulan ölçüm modelinin yapısal geçerliliğini ve ölçeklerin araştırmanın yapıldığı örneklemde de benzer olup olmadığını test etmek için önce, her ölçek için ayrı ayrı Açıklayıcı Faktör Analizi (AFA), sonra da Doğrulayıcı Faktör Analizi (DFA) yapılmış; yakınsak geçerliliğin (convergent validity) sağlanıp sağlanmadığını tespit etmek için ortalama açıklanan varyans (AVE) değerleri ve birleşik güvenilirlik (CR) alfa katsayıları hesaplanmış, ayırt edici (diskriminant) geçerliliğin sağlanıp sağlanmadığını tespit etmek için de gizil değişkenler arası korelasyon değerleri ve AVE değerlerinin karekökleri hesaplanmıştır. 
AFA sonuçlarına ilişkin bilgiler Tablo 2'de verilmiştir. İlk yapılan AFA sonuçlarına göre, EKD ölçeğinde yer alan K4 değişkeninin ortak varyans değeri tavsiye edilen değerden (Kalaycı, 2006: 329) çok düşük olduğu (0.258) için bu değişken ölçekten çıkarılarak faktör analizi tekrarlanmıştır. Sonuç olarak, tüm ölçekler için, KMO örneklem yeterlilik değerinin istenilen düzeyde (>0.5) olduğu ve bu sonuca göre örneklem yeterliliğinin çok iyi olduğu, Barlett Küresellik Testi sonucunun anlamlı olduğu ve bu sonuca göre veri setinin faktör analizine uygun olduğu, değişkenlerin ait oldukları faktörlere anlamlı ve yeterli düzeyde yüklendikleri sonucuna ulaşılmıştır (Kalaycı, 2006: 322).

Tablo 2. AFA Sonuçları

\begin{tabular}{|c|c|c|}
\hline Kod & Faktör & Faktör Yükleri \\
\hline EKMKT & \multicolumn{2}{|l|}{ Emoji Kullanan Markalara Karşı Tutum } \\
\hline T3 & Emoji kullanan marka olumludur & ,850 \\
\hline T4 & Emoji kullanan marka beğenilir & 835 \\
\hline T2 & Emoji kullanan marka iyidir & 804 \\
\hline T1 & Emoji kullanan marka çekicidir & ,789 \\
\hline T5 & Emoji kullanan marka sempatiktir & ,749 \\
\hline \multicolumn{3}{|c|}{ Açıklanan Toplam Varyans=64.990, KMO Değeri=0.837, Barlett Testi Ki-Kare Değeri=671.582 ve p=.000 } \\
\hline EKD & \multicolumn{2}{|l|}{ Emoji Kullanım Durumu } \\
\hline K6 & $\begin{array}{l}\text { Mesajlaşmalarımda (SMS, Whatsapp, Messenger vb.) kendimi ifade } \\
\text { etmek için emoji kullanırım }\end{array}$ & 822 \\
\hline K2 & Emoji kullanarak duygularımı daha kolay ifade ederim & 792 \\
\hline K7 & Arkadaşlarımla mesajlaşırken emoji kullanırım & ,792 \\
\hline K3 & Emoji kullanmak eğlencelidir & 776 \\
\hline K8 & Mesajlaşırken çok sık emoji kullanırım & 770 \\
\hline K1 & $\begin{array}{l}\text { Sosyal medya (Facebook, Instagram, Twitter vb.) hesaplarımda kendimi } \\
\text { ifade etmek için emoji kullanırım }\end{array}$ & 733 \\
\hline K5 & $\begin{array}{l}\text { Mesajlaşırken emoji içerikli bir mesaj geldiğinde, mesajlaştığım kişinin } \\
\text { duygularını daha iyi anlayabiliyorum }\end{array}$ & ,685 \\
\hline \multicolumn{3}{|c|}{ Açıklanan Toplam Varyans=59.043, KMO Değeri=0.880, Barlett Testi Ki-Kare Değeri=974.189 ve $p=.000$} \\
\hline EKMHWOMC & \multicolumn{2}{|l|}{ Emoji Kullanan Markalar Hakkındaki Pozitif WOMC } \\
\hline W2 & Birisi benden tavsiye istediğinde emoji kullanan markaları tavsiye ederim & 932 \\
\hline W1 & Arkadaş ve akrabalarıma emoji kullanan markaları tavsiye ederim & ,911 \\
\hline W3 & Markalar hakkında konuşuşken emoji kullanan markaları özellikle & 906 \\
\hline W4 & Daha önce emoji kullanan markaları arkadaşlarıma tavsiye ettim & 843 \\
\hline \multicolumn{3}{|c|}{ Açıklanan Toplam Varyans=80.752, KMO Değeri=0.845, Barlett Testi Ki-Kare Değeri=893.214 ve $p=.000$} \\
\hline
\end{tabular}

DFA sonuçları, AVE ve CR değerleri Tablo 4'te verilmiştir. Yapılan ilk DFA sonuçlarına göre, uyum iyiliği değerlerinin tavsiye edilen sınırlar dışında kaldığı tespit edilmiştir. Program tarafından önerilen modifikasyonlar yapılarak (EKD ölçeğinde bulunan K4 değişkeni için hesaplanan standardize edilmiş regresyon katsayısı 0.434 olarak tespit edildiği için bu değişken ölçekten çıkarılmıştır) DFA tekrarlanmış ve modele son şekli verilmiştir. Sonuç olarak, CMIN/DF ve GFI değerlerinin, Tablo 3'te belirtilen iyi uyum sınırları içinde, diğerlerinin kabul edilebilir uyum sınırları içinde kaldığı tespit edilmiştir.

DFA sonuçlarına göre, herbir ölçeğin tek faktörlü yapılarının doğrulandığı, herbir ölçekteki değişkenlerin ait oldukları ölçeğe anlamlı bir şekilde yüklendiği, herbir ölçeğin (gizil değişken), ölçekte yer alan ifadeler (gözlemlenen değişkenler) tarafından anlamlı bir şekilde açıklandığı ve daha önce literatürde çeşitli yazarlar tarafından geliştirilen ölçeklerin araştırmanın yapıldığı örneklemde de benzer olduğu söylenebilir (Meydan ve Şeşen, 2011: 14,21).

Yıldız ve Koç (2017)'un Fornell ve Larcker (1981)'den aktardığına göre, yakınsak geçerliliğin sağlanıp sağlanmadığını kontrol etmek için üç değere bakılır. Buna göre eğer, ölçeklerdeki her bir maddenin faktör yükü (standardize edilmiş $\beta$ değerleri) 0.50 'den büyük, AVE değeri 0.50 'ye eşit veya daha büyük ve CR alfa katsayısı 0.70 veya daha büyükse yakınsak geçerliliğin sağlandığı kabul edilmektedir. Tablo 4 'teki değerlere 
bakıldığında bu üç koşulun da sağlandığı görülmektedir. Buna göre araştırmada yakınsak geçerliliğin de sağlandığı söylenebilir.

Tablo 3. DFA Modeli Uyum Değerleri

\begin{tabular}{|c|c|c|}
\hline Uyum İstatistiği & İyi Uyum Sınırları & $\begin{array}{l}\text { Kabul Edilebilir } \\
\text { Uyum Sınırları }\end{array}$ \\
\hline CMIN/DF $\left(\chi^{2} / \mathrm{df}\right)$ & $0 \leq \chi^{2} / \mathrm{df} \leq 3$ & $4 \leq \chi^{2} / \mathrm{df} \leq 5$ \\
\hline $\mathrm{NFI}$ & $0,95 \leq \mathrm{NFI} \leq 1,00$ & $0,90 \leq \mathrm{NFI} \leq 0,94$ \\
\hline $\mathrm{CFI}$ & $0,97 \leq \mathrm{CFI} \leq 1,00$ & $0,95 \leq \mathrm{CFI} \leq 0,96$ \\
\hline RMSEA & $0 \leq \mathrm{RMSEA} \leq 0,05$ & $0,06 \leq \mathrm{RMSEA} \leq 0,08$ \\
\hline GFI & $0,90 \leq \mathrm{GFI} \leq 1,00$ & $0,85 \leq \mathrm{GFI} \leq 0,89$ \\
\hline AGFI & $0,90 \leq \mathrm{AGFI} \leq 1,00$ & $0,85 \leq \mathrm{AGFI} \leq 0,89$ \\
\hline \multicolumn{3}{|c|}{$\begin{array}{l}\text { CMIN }\left(\chi^{2}\right) \text { : Chi-Square (Ki-Kare Değeri), DF: Degree of Freedom (Serbestlik Derecesi), NFI:Normed Fit Index } \\
\text { (Normlandırılmış Uyum İndeksi), CFI:Comparative Fit Index (Karşılaştırmalı Uyumj İndeksi), RMSEA:Root Mean Square } \\
\text { Error of Approximation (Yaklaşık Hataların Ortalama Kare Kökü), GFI: Goodness of Fit Index (Uyum İiliği İndeksi), AGFI: } \\
\text { Adjusted Goodness of Fit Index (Düzeltilmiş Uyum İyiliği İndeksi) }\end{array}$} \\
\hline
\end{tabular}

Tablo 4. DFA Sonucu Standardize Edilmiş Faktör Yükleri, Anlamlııık, AVE ve CR Değerleri

\begin{tabular}{|c|c|c|c|c|c|}
\hline Kod & Faktör & $\begin{array}{c}\text { Standardize } \\
\text { Edilmiş } \beta \\
\text { Değerleri }\end{array}$ & $\begin{array}{l}\text { Anlamlılık } \\
\text { (p) }\end{array}$ & AVE & CR \\
\hline EKD & \multicolumn{5}{|l|}{ Emoji Kullanım Durumu } \\
\hline K1 & $\begin{array}{l}\text { Sosyal medya (Facebook, Instagram, } \\
\text { Twitter vb.) hesaplarımda kendimi ifade } \\
\text { etmek için emoji kullanırım }\end{array}$ & 0.698 & 0.000 & \multirow{7}{*}{0.507} & \multirow{7}{*}{0.877} \\
\hline K2 & Emoji kullanarak duygularımı daha kolay & 0.780 & 0.000 & & \\
\hline K3 & Emoji kullanmak eğlencelidir & 0.757 & 0.000 & & \\
\hline K5 & $\begin{array}{l}\text { Mesajlaşırken emoji içerikli bir mesaj } \\
\text { geldiğinde, mesajlaştığım kişinin } \\
\text { duygularını daha iyi anlayabiliyorum }\end{array}$ & 0.603 & 0.000 & & \\
\hline K6 & $\begin{array}{l}\text { Mesajlaşmalarımda (SMS, Whatsapp, } \\
\text { Messenger vb.) kendimi ifade etmek için } \\
\text { emoji kullanırım }\end{array}$ & 0.759 & 0.000 & & \\
\hline K7 & $\begin{array}{l}\text { Arkadaşlarımla mesajlaşırken emoji } \\
\text { kullanırım }\end{array}$ & 0.692 & 0.000 & & \\
\hline K8 & Mesajlaşırken çok sık emoji kullanırım & 0.681 & 0.000 & & \\
\hline EKMKT & \multicolumn{5}{|l|}{ Emoji Kullanan Markalara Karşı Tutum } \\
\hline $\mathrm{T} 1$ & Emoji kullanan marka çekicidir & 0.744 & 0.000 & \multirow{5}{*}{0.547} & \multirow{5}{*}{0.858} \\
\hline T2 & Emoji kullanan marka iyidir & 0.696 & 0.000 & & \\
\hline T3 & Emoji kullanan marka olumludur & 0.757 & 0.000 & & \\
\hline T4 & Emoji kullanan marka beğenilir & 0.788 & 0.000 & & \\
\hline T5 & Emoji kullanan marka sempatiktir & 0.711 & 0.000 & & \\
\hline EKMHWOMC & \multicolumn{5}{|c|}{ Emoji Kullanan Markalar Hakkındaki Pozitif Ağızdan Ağıza İletișim } \\
\hline W1 & $\begin{array}{l}\text { Arkadaş ve akrabalarıma emoji kullanan } \\
\text { markaları tavsiye ederim }\end{array}$ & 0.886 & 0.000 & \multirow{4}{*}{0.746} & \multirow{4}{*}{0.921} \\
\hline W2 & $\begin{array}{l}\text { Birisi benden tavsiye istediğinde emoji } \\
\text { kullanan markaları tavsiye ederim }\end{array}$ & 0.929 & 0.000 & & \\
\hline W3 & $\begin{array}{l}\text { Markalar hakkında konuşuşken emoji } \\
\text { kullanan markaları özellikle vurgularım }\end{array}$ & 0.875 & 0.000 & & \\
\hline W4 & $\begin{array}{l}\text { Daha önce emoji kullanan markaları } \\
\text { arkadaşlarıma tavsiye ettim }\end{array}$ & 0.756 & 0.000 & & \\
\hline
\end{tabular}


Ayırt edici (diskriminant) geçerlilik değerleri Tablo 5'te verilmiştir.

Tablo 5. Ayırt Edici (Diskriminant) Geçerliliği Test Etmek İçin Hesaplanan Gizil Değişkenler Arası Korelasyon Matrisi ve AVE Değerlerinin Karekökleri

\begin{tabular}{|l|c|c|c|}
\hline & EKD & EKMKT & EKMHWOM \\
\hline EKD &, $712 *$ & & \\
\hline EKMKT &, 353 &, $740^{*}$ & \\
\hline EKMHWOM &, 281 &, 558 &, $864^{*}$ \\
\hline \multicolumn{4}{|c|}{${ }^{*}$ AVE değerlerinin karekökleri } \\
\hline
\end{tabular}

Ayırt edici (diskriminant) geçerliliğin sağlanabilmesi için AVE değerlerinin kareköklerinin gizil değişkenler arası korelasyon değerlerinden büyük olması gerekmektedir (Kandemir, 2016: 320). Tabloya bakıldığında EKD, EKMKT ve EKMHWOMC gizil değişkenlerinin AVE değerlerinin kareköklerinin bu değişkenler arasındaki korelasyon değerlerinden büyük olduğu görülmektedir. Buna göre ayırt edici (diskriminant) geçerliliğin sağlandığı söylenebilir.

\section{Bulgular}

Araştırmaya katılan cevaplayıcıların \%58.3'ü kız (169 öğrenci), \%41.7'si erkek (121 öğrenci)'tir. Cevaplayıcıların yaş aralığı 18-27 arasında değişmekle birlikte büyük çoğunluğu (\%93.8) 19-24 yaş aralığındadır ve yaş ortalaması $21,45^{\prime}$ tir. Cevaplayıcılar aylık ortalama 629,05 TL harcama yapmaktadır.

\subsection{Yapısal Eşitlik Modeli}

Araştırmanın hipotezlerini test etmek için Yapısal Eşitlik Modelinden (YEM) faydalanılmıştır. Model test edildikten sonra program tarafından önerilen modifikasyonlar yapılarak modele son şekli verilmiştir.

\subsubsection{EKD’nin EKMKT, EKMKT’nin de EKMHWOMC Üzerindeki Etkisini Gösteren Yapısal Eşitlik Modeli}

$H_{1}$ ve $H_{2}$ hipotezlerini test etmek için oluşturulan YEM, Şekil 2'de gösterilmiştir.

Şekil 2. EKD’nin EKMKT, EKMKT'nin de EKMHWOMC Üzerindeki Etkisini Gösteren YEM

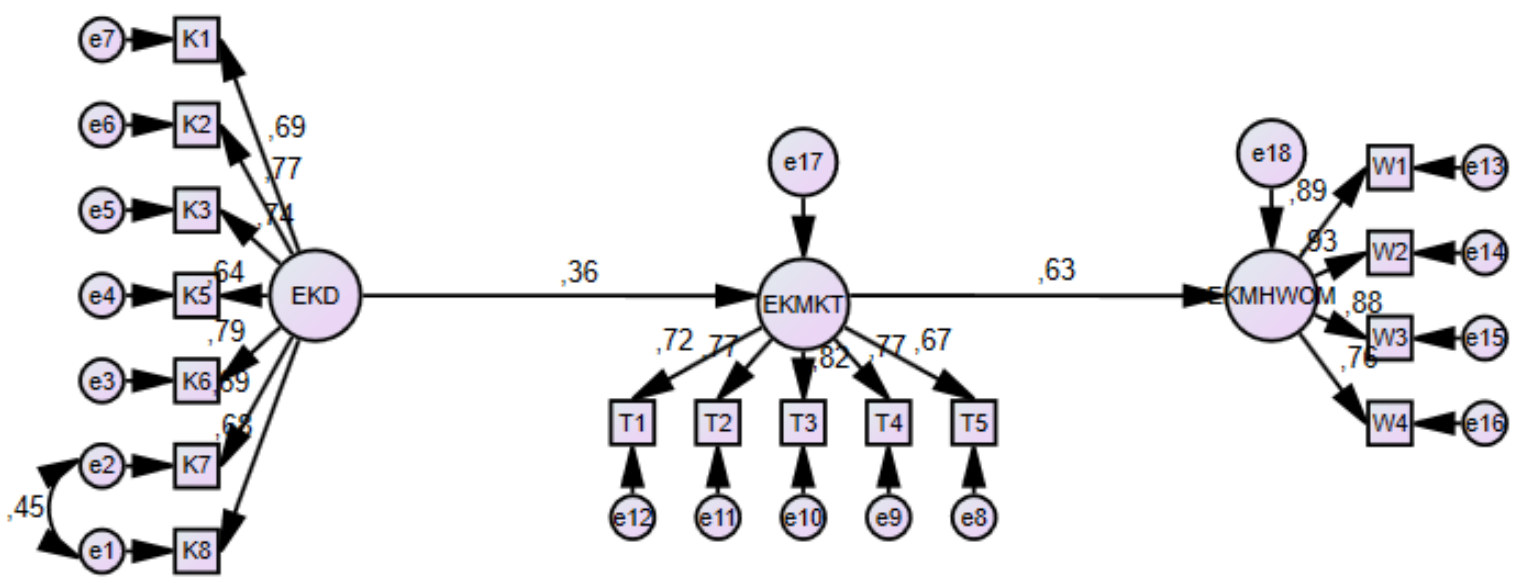

Uyum Iyiliği Değerleri: $C M I N / D F=2.454, N F I=0.914, C F I=0.947, R M S E A=0.071, G F I=0.901, A G F I=0.866$ 
Model test edildiğinde CMIN/DF hariç (CMIN/DF=2.927) diğer uyum iyiliği değerlerinin ( $N F I=0.896$, $\mathrm{CFI}=0.928, \mathrm{RMSEA}=0.81, \mathrm{GFI}=0.882, \mathrm{AGFI}=0.842$ ) kabul edilebilir sınırlar dışında olduğu görülmüştür. Uyum iyiliği değerlerini iyileştirmek için program tarafından önerilen modifikasyonlardan, EKD ölçeğinde yer alan K7 ve K8 değişkenlerinin hata terimleri arasında kovaryans oluşturulmuştur. Bu iki değişken de öğrencilerin mesajlaşmalarında emoji kullanımı ile ilgilidir. Dolayısıyla bu iki değişkenin hata terimleri arasında yüksek ilişki çıkması doğal kabul edilebilir. Literatürde de benzer durumlarda değişkenlerin hata terimleri arasında kovaryans oluşturulduğu görülmektedir (Sütütemiz, 2005:165-166). Bu nedenle, bu iki değişkenin hata terimleri arasında kovaryans oluşturularak model yeniden test edilmiştir.

Test edilen son modelin uyum iyiliği değerlerine bakıldığında, CMIN/DF ve GFI değerlerinin iyi uyum sınırları, diğer değerlerin ise kabul edilebilir uyum sınırları (içinde olduğu görülmektedir (Meydan ve Şeşen, 2011:37). Bu değerler, oluşturulan modelin uyum değerlerinin iyi ve kabul edilebilir sınırlar içinde olduğunu ve modelin yapısal olarak uygun olduğuna ilişkin yeterli kanıtları sağlamaktadır.

Oluşturulan modele ilişkin standardize edilmiş regresyon katsayıları ( $\beta$ katsayısı), standart hata ve anlamlılık değerleri ( $p$ değeri) Tablo 6 'da gösterilmiştir.

Tablo 6. Yapısal Eşitlik Modeli Yol Analizi Sonuçları

\begin{tabular}{|l|c|l|c|c|c|}
\hline \multicolumn{2}{|c|}{ Değişkenler Arası Ilişkiler } & Standardize Edilmiş $\boldsymbol{\beta}$ & $\begin{array}{c}\text { Standart } \\
\text { Hata }\end{array}$ & $\begin{array}{c}\text { Anlamlılık } \\
\text { (p değeri) }\end{array}$ \\
\hline EKD & $--->$ & EKMKT & 0.365 & 0.072 & 0.000 \\
\hline EKMKT & $-->>$ & EKMHWOMC & 0.628 & 0.104 & 0.000 \\
\hline
\end{tabular}

Yapısal eşitlik modelinde değişkenler arası elde edilen etki katsayıları yorumlanırken, standardize edilmiş $\beta$ değeri 0.10 'dan az ise küçük, $0.10-0.30$ arasında ise orta, 0.50 ve daha fazla ise yüksek düzeyde etkiden bahsedilebilir (Öztürk ve Okumuş, 2017:552). Elde edilen bulgular incelendiğinde, öğrencilerin emoji kullanım durumlarının (EKD), emoji kullanan markalara karşı tutumları (EKMKT) üzerinde istatistiksel açıdan anlamlı, pozitif yönlü ve orta derecede bir etkiye sahip olduğu $(\beta=0.4365 ; p<0.001)$ görülmektedir. Öğrencilerin emoji kullanan markalara karşı tutumlarının (EKMKT) emoji kullanan markalar hakkındaki pozitif ağızdan ağıza iletişimleri (EKMHWOMC) üzerinde ise, istatistiksel açıdan anlamlı, pozitif yönlü ve yüksek derecede bir etkiye sahip olduğu $(\beta=0.628 ; p<0.001)$ görülmektedir. Bu sonuçlara göre $H_{1}$ ve $H_{2}$ hipotezleri kabul edilmiştir.

\subsubsection{Cinsiyet Açısından EKD’nin EKMKT, EKMKT’nin de EKMHWOMC Üzerindeki Etkisini Gösteren Çoklu Grup Yapısal Eşitlik Modeli}

Araştırmada EKD'nin EKMKT, EKMKT'nin de EKMHWOMC üzerindeki etkisi cinsiyet açısından incelenmiştir. Bunun için çoklu grup yapısal eşitlik modellemesi uygulanmıştır.

Gruplararası karşılaştırmalara geçmeden önce ölçme değişmezliğinin sağlanıp sağlanmadığı test edilmiştir. Ölçme değişmezliğinin test edilmesinde Meredith (1993) tarafından önerilen dört aşamalı süreç ve hipotez test etme yöntemi izlenmiştir (Meredith 1993'ten aktaran Başusta ve Gelbal, 2015:81-82). Önerilen dört değişmezlik (biçimsel, metrik, ölçek ve katı değişmezlik) ile ilgili sonuçlar Tablo 7' teki gibidir. Tabloda yer alan Model A, herhangi bir sınırlandırma getirilmemiş (faktör yükleri, faktör korelasyonları ve hata varyansları serbest olan) modeli, Model B, faktör yüklerinin sınırlandırıldığı (faktör yükleri sabit, faktör korelasyonları ve hata varyansları serbest olan) modeli, Model C, faktör yükleri ve faktör korelasyonlarının sınırlandırıldığı (faktör yükleri ve faktör korelasyonları sabit, hata varyansları serbest olan) modeli ve Model D ise, faktör yükleri, faktör korelasyonları ve hata varyanslarının sınırlandırıldığı (faktör yükleri, faktör korelasyonları ve hata varyansları sabit olan) modeli göstermektedir (Başusta ve Gelbal, 2015:86). 
Üniversite Öğrencilerinin Emoji Kullanımları ve Emoji Kullanan Markalara Karşı Tutumları Üzerine Bir Araştırma

Tablo 7. Ölçme Değişmezliği Aşamaları Ile İlgili Uyum İyiliği Değerleri

\begin{tabular}{|l|c|c|c|c|c|c|c|c|c|c|c|}
\hline Aşamalar & $\chi^{2}$ & $\mathbf{s d}$ & $\chi_{2} / \mathbf{s d}$ & $\boldsymbol{\Delta}_{\chi 2}$ & $\mathbf{p}$ & $\mathbf{R M S E A}$ & $\mathbf{\Delta R M S E A}$ & $\mathbf{G F I}$ & $\mathbf{\Delta G F I}$ & CFI & $\Delta$ CFI \\
\hline $\begin{array}{l}\text { Model A } \\
\text { (Biçimsel } \\
\text { Değişmezlik) }\end{array}$ & 387.934 & 200 & 1.940 & - & - & .057 & - & .859 & - & .931 & - \\
\hline $\begin{array}{l}\text { Model B } \\
\text { (Metrik } \\
\text { Değişmezlik) }\end{array}$ & 396.058 & 213 & 1.859 & 8.124 & .835 & .055 & .002 & .858 & .001 & .933 & -.002 \\
\hline $\begin{array}{l}\text { Model C } \\
\text { (Ölç̧ek } \\
\text { Değişmezliği) }\end{array}$ & 401.522 & 219 & 1.833 & 5.464 & .807 & .054 & .001 & .857 & .001 & .933 & .000 \\
\hline $\begin{array}{l}\text { Model D (Katı } \\
\text { Değişmezlik) }\end{array}$ & 471.102 & 236 & 1.996 & 69.58 & .000 & .059 & -.005 & .831 & .026 & .914 & .019 \\
\hline
\end{tabular}

Literatürde ölçme değişmezliği çalışmalarında Ki-Kare değerleri arasında fark ve farkın anlamlılığı ( $p>0.05$ ), CFI, GFI, RMSEA değerleri arasındaki farklar (-0.01 ile 0.01 arasında ise gruplar için değişmezlik şartı sağlanmaktadır) kullanılmaktadır. Literatürde $\triangle$ CFI değerlerinin kullanılmasının tavsiye edilmesine rağmen (Başusta ve Gelbal, 2015:85; Cheung ve Rensvold 2002'den aktaran Ursavaş, Şahin ve McInlroy, 2014:901) diğer uyum katsayılarının da kullanılabileceği belirtilmektedir (Başusta ve Gelbal, 2015:85).

Tablo 7 incelendiğinde uyum iyiliği değerleri kabul edilebilir sınırlar içinde olduğu için biçimsel değişmezliğin sağlandığı görülmektedir. Diğer yandan $\Delta \chi^{2}, \triangle \mathrm{RMSEA}, \triangle \mathrm{GFI}, \triangle \mathrm{CFI}$ sonuçlarına göre metrik değişmezlik ve ölçek değişmezliğinin sağlandığı, katı değişmezliğin ise sadece $\triangle R M S E A$ sonucuna göre sağlandığı görülmektedir. Nitekim Ko Y.J. vd.,'ne göre, diğer kriterlere göre değişmezlik sağlanamamasına rağmen, $\triangle R M S E A$ değerinin 0.01 'den küçük olması durumunda değişmezliğin sağlandığı söylenebilir (Ko Y.J. v.d., 2016:6). Bu sonuçlara göre, çoklu grup yapısal eşitlik testinde ölçme değişmezliğinin sağlandığı ve oluşturulan model çerçevesinde, cinsiyete göre yapılan karşılaştırmaların anlamlı olduğu söylenebilir (Başusta ve Gelbal, 2015:87).

Çoklu grup yapısal eşitlik modeli testi sonucunda, kız öğrenciler için oluşturulan yol modeli Şekil 3'te erkek öğrenciler için oluşturulan yol modeli ise Şekil 4'te gösterilmiştir.

Şekil 3. Kız Öğrenciler İçin EKD’nin EKMKT, EKMKT'nin de EKMHWOMC Üzerindeki Etkisini Gösteren YEM

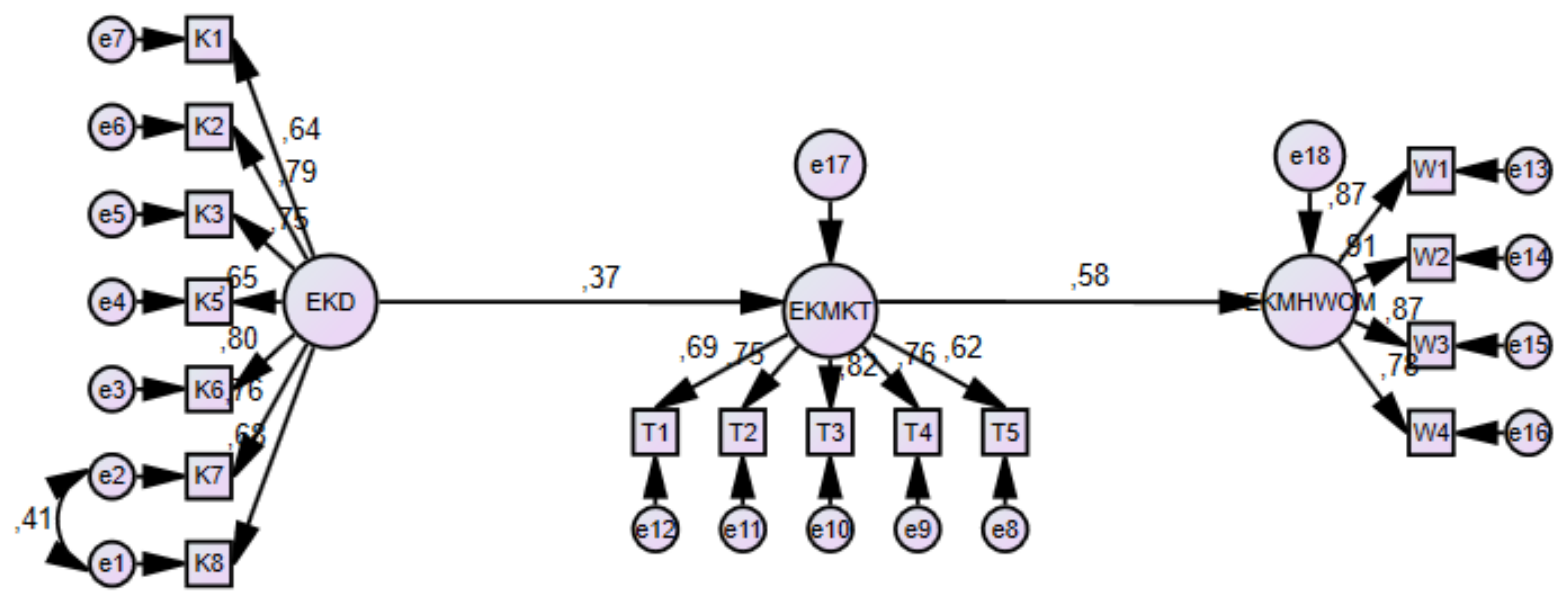


Şekil 4. Erkek Öğrenciler İçin EKD’nin EKMKT, EKMKT'nin de EKMHWOMC Üzerindeki Etkisini Gösteren YEM

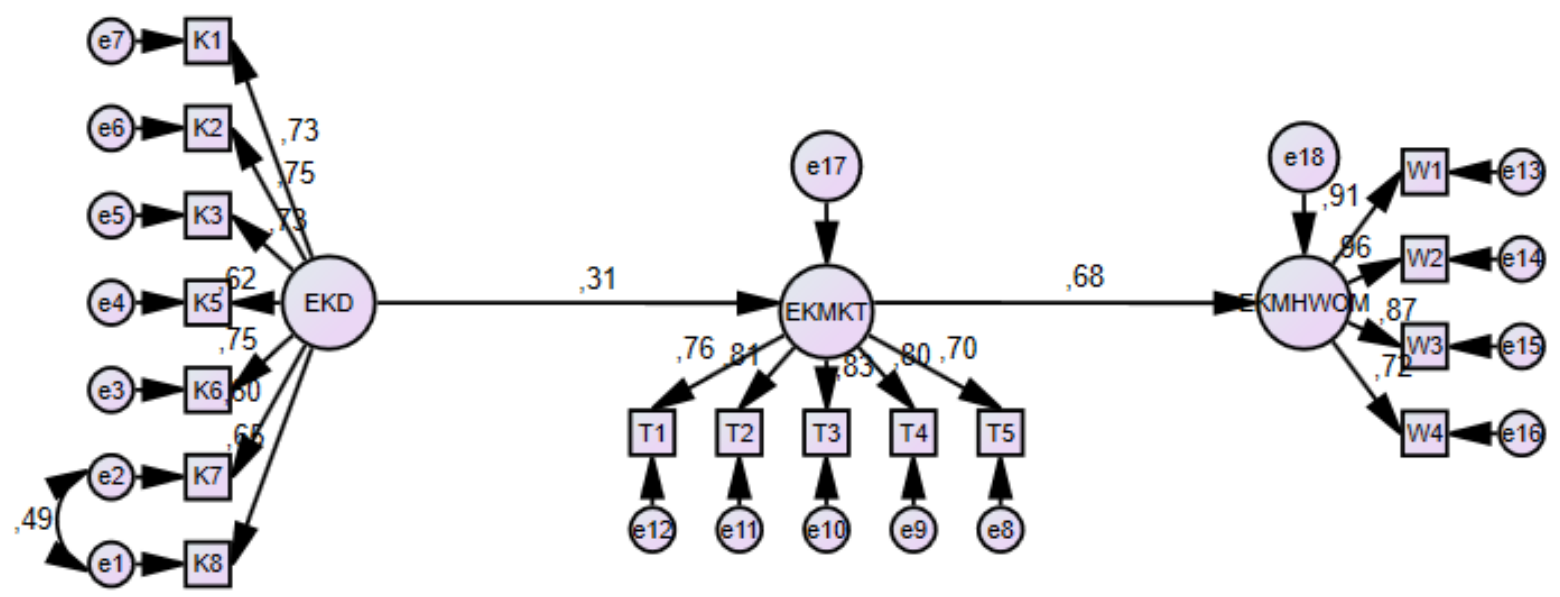

Oluşturulan modellere ilişkin standardize edilmiş regresyon katsayıları ( $\beta$ katsayısı), standart hata ve anlamlılık değerleri ( $p$ değeri) Tablo 8'de gösterilmiştir.

Tablo 8. Kız ve Erkek Öğrenciler İçin Oluşturulan Yapısal Eşitlik Modeli Yol Analizi Sonuçları

\begin{tabular}{|l|l|c|l|c|c|c|}
\hline \multirow{2}{*}{ Cinsiyet } & \multicolumn{3}{|c|}{ Değişkenler Arası Ilişkiler } & Standardize Edilmiş $\boldsymbol{\beta}$ & $\begin{array}{c}\text { Standart } \\
\text { Hata }\end{array}$ & $\begin{array}{c}\text { Anlamlılık } \\
\text { (p değeri) }\end{array}$ \\
\hline \multirow{2}{*}{ KIZ } & EKD & $--->$ & EKMKT & 0.371 & 0.090 & 0.000 \\
\cline { 2 - 7 } & EKMKT & $--->$ & EKMHWOMC & 0.585 & 0.155 & 0.000 \\
\hline \multirow{2}{*}{ Erkek } & EKD & $--->$ & EKMKT & 0.313 & 0.123 & 0.004 \\
\cline { 2 - 7 } & EKMKT & $--->$ & EKMHWOMC & 0.682 & 0.147 & 0.000 \\
\hline
\end{tabular}

Elde edilen bulgular incelendiğinde, kız öğrencilerin emoji kullanım durumlarının (EKD), emoji kullanan markalara karşı tutumları (EKMKT) üzerinde istatistiksel açıdan anlamlı, pozitif yönlü ve orta derecede bir etkiye sahip olduğu $(\beta=0.439 ; p<0.001)$ görülmektedir. Diğer yandan kız öğrencilerin emoji kullanan markalara karşı tutumlarının da (EKMKT) emoji kullanan markalar hakkındaki pozitif ağızdan ağıza iletişimleri (EKMHWOMC) üzerinde ise, istatistiksel açıdan anlamlı, pozitif yönlü ve yüksek derecede bir etkiye sahip olduğu $(\beta=0.566 ; p<0.001)$ görülmektedir. Bu sonuçlara göre $H_{1 a}$ ve $H_{2 a}$ hipotezleri kabul edilmiştir. Benzer şekilde erkek öğrencilerin emoji kullanım durumlarının (EKD), emoji kullanan markalara karşı tutumları (EKMKT) üzerinde istatistiksel açıdan anlamlı, pozitif yönlü ve orta derecede bir etkiye sahip olduğu $(\beta=0.310 ; p<0.001)$ görülmektedir. Diğer taraftan erkek öğrencilerin emoji kullanan markalara karşı tutumlarının da (EKMKT) emoji kullanan markalar hakkındaki pozitif ağızdan ağıza iletişimleri (EKMHWOMC) üzerinde ise, istatistiksel açıdan anlamlı, pozitif yönlü ve yüksek derecede bir etkiye sahip olduğu ( $\beta=0.670$; $\mathrm{p}<0.001$ ) görülmektedir. Bu sonuçlara göre $\mathrm{H}_{1 b}$ ve $\mathrm{H}_{2 b}$ hipotezleri kabul edilmiştir.

Cinsiyete göre değişkenler arası ilişkiler incelendiğinde, her iki grup (kızlar ve erkekler) için de öğrencilerin emoji kullanım durumlarının (EKD), emoji kullanan markalara karşı tutumları (EKMKT) ve emoji kullanan markalara karşı tutumlarının da (EKMKT) emoji kullanan markalar hakkındaki pozitif ağızdan ağıza iletişimleri (EKMHWOMC) üzerinde anlamlı etkiye sahip olduğu görülmektedir. Bununla birlikte, öğrencilerin emoji kullanım durumlarının (EKD), emoji kullanan markalara karşı tutumları (EKMKT) üzerindeki etkisi kız öğrencilerde daha kuvvetli çıkarken, tam tersi emoji kullanan markalara karşı tutumların (EKMKT), emoji kullanan markalar hakkındaki pozitif ağızdan ağıza iletişimleri (EKMHWOMC) üzerindeki etkisi erkek öğrencilerde daha kuvvetli çıkmıştır.

Bahsedilen değişkenler arası bu etkilerin cinsiyete açısından istatistiki olarak farklı olup olmadığı da araştırılmıştır. Yapısal modelle ilgili yapılacak bu tür karşılaştırmalarda çoklu grup testi sonucu elde edilen 
Üniversite Öğrencilerinin Emoji Kullanımları ve Emoji Kullanan Markalara Karşı Tutumları Üzerine Bir Araştırma

standardize edilmemiş değerler kullanılabilmektedir. Gruplar arası regresyon katsayılarının karşılaştırılmasında, $\mathrm{z}=(\mathrm{b} 1-\mathrm{b} 2) / \sqrt{\mathrm{SEb} 1^{2}+\mathrm{SEb}^{2}}$ (b1,b2: standardize edilmemiş yol katsayıları, SEb12, SEb22: hata varyansları) formülü genel olarak kullanılmaktadır. Eğer z değeri \%95 güven düzeyinde 1,96'dan büyük ise regresyon katsayılarının büyüklüklerinin anlamlı olarak farklı olduğu yorumu yapılabilmektedir (Öztürk ve Okumuş, 2017:554). Sonuçlara göre, cinsiyet açısından EKD ile EKMT arasındaki ilişki için hesaplanan z değeri -0.039; EKMT ile EKMHWOMC arasındaki ilişki için hesaplanan z değeri ise -0.159 olarak hesaplanmıştır. Bu sonuçlara göre cinsiyet açısından değişkenler arası etkilerin istatistiki olarak anlamlı farklılık göstermediği sonucuna ulaşılmıştır.

\section{Sonuç, Kısıtlar ve Öneriler}

Sözsüz iletişim unsurlarının yerine kullanılması anlamında dijital iletişimde önemli bir boşluğu doldurduğu düşünülen emojilerin markaya yönelik tutuma ve ağızdan ağıza iletişime etkisinin olup olmadığı sorusu, bu araştırmanın çıkış noktasını oluşturmaktadır. Üniversite öğrencileri üzerinde yapılan araştırmada, öğrencilerin emoji kullanımlarının emoji kullanan markalara yönelik tutumları üzerinde istatistiksel açıdan anlamlı ve pozitif yönlü bir etkiye sahip olduğu, emoji kullanan markalara yönelik tutumlarının da emoji kullanan markalar hakkındaki pozitif ağızdan ağıza iletişimleri üzerinde anlamlı ve pozitif yönlü bir etkiye sahip olduğu sonucuna ulaşılmıştır. Bu bulgular daha önce Gökaliler ve Saatçioğlu (2016)'nun emoji içerikli reklamlara yönelik tüketici tutumlarını araştırdıkları çalışmanın bulgularıyla benzerlik göstermektedir. Araştırmaya göre tüketicilerin emoji kullanımları arttığında, emoji içerikli reklamlara yönelik tutumları da olumlu yönde artmaktadır. Benzer şekilde bu çalışmada da tüketicilerin emoji kullanımlarının emoji kullanan markalara yönelik tutumlarını olumlu yönde etkilediği sonucuna ulaşılmıştır. Bu bulgular ayrıca daha önce Qui vd. (2016) tarafından yapılan araştırmanın bulgularıyla da paralellik göstermektedir. Duygu ikonlarının ağızdan ağıza iletişimde mesajın ikna ediciliği üzerinde etkili olduğu gibi bu çalışmada da emoji kullanımının pozitif ağızdan ağıza iletişim üzerinde etkili olduğu bulunmuştur.

Bu bulgulardan hareketle, emoji kullanan tüketicilerin emoji kullanan markalar ile kendilerini özdeşleştirdiği ileri sürülebilir. Daha önce yapılan çalışmalar markaya yönelik pozitif tutumların (Kotler ve Keller, 2008) ve tüketicinin öz kimlik ve marka/ ürün imajı arasındaki uyum düzeyinin artmasının (Ekinci ve Riley, 2003) o ürün ya da markaya yönelik satın alma niyetini de artırdığı sonucuna ulaşmıştır. Bu açıdan ileride yapılacak çalışmalarda emoji kullanan markaların imajı ve tüketicilerin öz kimlik uyumu arasındaki ilişkiler incelenebilir.

Çalışma sonucunda, kız öğrencilerin emoji kullanım durumlarının emoji kullanan markalara karşı tutumları üzerindeki etkisinin erkek öğrencilere göre daha güçlü olduğu, ancak emoji kullanan markalara karşı tutumların, erkek öğrencilerde daha güçlü bir pozitif ağızdan ağıza iletişime yol açtığı bulunmuştur. Bu bulgular cinsiyetin ağızdan ağıza iletişim üzerindeki etkisiyle ilgili daha önce yapılan bazı çalışmaların bulgularını desteklemektedir. Örneğin, Choi ve Kim (2014) ağızdan ağıza iletişim ve benlik sunumu arasındaki ilişki üzerinde cinsiyetin aracılık etkisini araştırdıkları çalışmalarında erkeklerin özellikle benlik sunumu söz konusu olduğunda kadınlara göre markalarla ilgili daha fazla ağızdan ağıza iletişim içeriği paylaştıklarını bulmuşlardır. Emoji kullanımının cinsiyet ile ilişkisine bakıldığında, daha önce yapılan bazı çalışmalarda (Hwang, 2014; Lee 2003) çevrimiçi ortamda duyguları ifade etmek açısından kadınların erkeklere oranla daha fazla duygu ikonu ya da emoji kullandıkları görülmüştür. Başka bir çalışmada (Wolf, 2000) internet ortamında duygu paylaşımı söz konusu olduğunda erkeklerin daha fazla duygu ikonu kullanarak duyguları ifade etmede kadın standartlarını benimsediği bulunmuştur. Bu çalışmada ise cinsiyet açısından değişkenler arası etkilerin istatistiki olarak anlamlı farklılık göstermediği sonucuna ulaşılmıştır. Konu ile ilgili farklı bulguların olması açısından ileride yapılacak çalışmalarda emoji kullanımında cinsiyet farklılıklarının araştırılmasının literatüre katkıda bulunacağı düşünülmektedir.

Araştırmanın sadece öğrenciler üzerinde gerçekleştirilmiş olması, sonuçların genellenmesini kısıtlamakla birlikte, elde edilen bulguların daha sonra yapılacak çalışmalara yol göstereceği de düşünülmektedir. İleride yapılacak çalışmalarda faklı hedef kitlelerin emoji kullanımlarının araştırılması da bulguların genellebilirliğine katkıda bulunacaktır. Ayrıca, emoji kullanımının marka farkındalığı, marka kişiliği 
gibi konularla ilişkisinin araştırılmasının pazarlama literatürü açısından önem arz ettiği düşünülmektedir. Özellikle, göstergebilimin kullanılacağı araştırmalar, emojilerin anlamlandırılması açısından literatüre katkıda bulunacaktır.

\section{Kaynaklar}

Agarwal, J., \& Malhotra, N. (2005). An integrated model of attitude and affect. Journal of Business Research, 58(4), 483493.

Anderson, E. W. (1998). Customer satisfaction and word of mouth. Journal of Service Research, 1(1), 5-17.

Arndt, J. (1967). Role of product-related conversations in the diffusion of a new product. Journal of Marketing Search, 4(3), 291-295.

Başusta, N. B., \& Gelbal, S. (2015). Gruplararası karşılaştırmalarda ölçme değişmezliğinin test edilmesi: PISA öğrenci anketi örneği. Hacettepe Üniversitesi Eğitim Fakültesi Dergisi, 30(4), 80-90.

Bloom, H. (2000). Global brain: The evolution of mass mind from the big bang to the 21st century. John Wiley \& Sons: USA

Brown, J., Broderick, A. J., \& Lee, N. (2007). Word of mouth communication within online communities: Conceptualizing the online social network. Journal of Interactive Marketing, 21(3), 2-20.

Buehner, T. M., \& Sommerfeldt, E.J. (2013). Visual communication in the public sphere. American Communication Journal, 15(3), 1-13.

Cheung, G. W., \& Rensvold, R. B. (2002). Evaluating goodness-of-fit indexes for testing measurement invariance. Structural Equation Modeling, 9(2), 233-255.

Choi, J., \& Kim, Y. (2014). The moderating effects of gender and number of friends on the relationship between selfpresentation and brand-related word-of-mouth on Facebook. Personality and Individual Differences, 68, 1-5.

Cohn, N. (2015). Will emoji become a new language? BBC Future, http://www.bbc.com/future/story/20151012-willemoji-become-a-new-language

Cowie, R., Douglas-Cowie, E., Tsapatsoulis, N., Votsis, G., Kollias, S., Fellenz, W., \& Taylor, J. G. (2001). Emotion recognition in human-computer interaction. IEEE Signal Processing Magazine, 18, 32-80.

Danesi, M. (2017). The semiotics of emoji: The rise of visual language in the age of the internet. Bloomsbury Academic: London.

Davis, M., \& Edberg, P. (2015). Unicode emoji, technical report 51. http://unicode.org/L2/L2015/15040-utr51-1d5.pdf

Derks, D., Bos, A., \& Grumbkow, J. (2007). Emoticons and social interaction on the internet: The importance of social context. Computers in Human Behavior, 23, 842-849.

Derks, D., Fischer, A. H., \& Bos, A. E. (2008). The role of emotion in computer-mediated communication: A review. Computers in Human Behavior, 24, 766-785

Dimson, T. (2015). Emojineering part 1: Machine learning for emoji trends. Available at https://engineering.instagram.com/emojineering-part-1-machine-learning-for-emoji-trendsmachine-learningfor-emoji-trends-7f5f9cb979ad

Duhan, D. F., Johnson, S. D., Wilcox, J. B., \& Harrell, G. D. (1997). Influences on consumer use of word-of-mouth recommendation sources. Journal of the Academy of Marketing Science, 25(4), 283-295.

Ekinci, Y., \& Riley, M. (2003). An investigation of self-concept: Actual and ideal self-congruence compared in the context of service evaluation. Journal of Retailing and Consumer Services, 10, 201-214.

Emoji Report (2016). https://emogi-www-cdn.s3.amazonaws.com/uploads/2017/05/2016-Emoji-Report-_Final-1.pdf

Ennew, C. T., Ashish, K. B., \& Derek L. (2000). Managing word of mouth communication: Empirical evidence from India. International Journal of Bank Marketing, 18(2), 75- 83.

Feldwick, P. (1996). Do we really need brand equity? Journal of Brand Management, 4(1), 9-28.

Fornell, C., \& Larcker, D. F. (1981). Evaluating structural equation models with unobservable variables and measurement error. Journal of Marketing Research, 48, 39-50.

Gaffey, C. (2015). Are emojis becoming the new universal language. Newsweek, http://www.newsweek.com/emojiemojisemoji-meaningemoji-languageemoji-communicationemojiunicodevyv-600005 
Garson, D. (2012). Testing statistical assumptions. Statistical Associates Publishing-Blue Book Series, Asheboro.

Gökaliler E., \& Saatçioğlu E. (2016). Reklamlarda emoji kullanımı: Emoji içerikli reklamlara yönelik tüketicilerin tutumlarının belirlenmesi üzerine bir araştırma. Selçuk Üniversitesi Sosyal Bilimler MYO Dergisi, 19(2), 63-91.

Gremler, D. D., Gwinner, K.P., \& Brown, S. W. (2001). Generating positive word-of-mouth communication through customer-employee relationships. International Journal of Service Industry Management, 12(1), 44-59.

Gremler, D. D., \& Gwinner, K. P. (2000). Customer-employee rapport in service relationships. Journal of Service Research, 3(1), 82-104.

Hair, F. J., Black, C. W., Babin, J. B., Anderson, E. R., \& Totham, L.R. (2005). Multivariate data analysis. Sixth Edition. New Jersey: Pearson Prentice Hall.

Harris, A., \& Prideaux, B. (2017). The potential for eWOM to affect consumer behaviour in tourism. In SK Dixit (ed.) The Routledge Handbook of Consumer Behaviour in Hospitality and Tourism, Routledge, Abingdon, UK.

Highfield, T., \& Leaver, T. (2016). Instagrammatics and digital methods: Studying visual social media, from selfies and GIFs to memes and emoji. Communication Research and Practice, 2(1), 47-62.

Hill, J. H. (2016). The impact of emojis and emoticons on online consumer reviews, perceived company response quality, brand relationship and purchase intent. University of South Florida, Master Thesis, http://scholarcommons.usf.edu/etd/6513/

https://emojipedia.org/emoji-5.0/ (Erişim Tarihi: 30.01.2018).

Hwang, H.S. (2014). Gender differences in emoticon use on mobile text messaging: Evidence from a Korean sample. International Journal of Journalism \& Mass Communication, 1(107).

Hwang, J., Yoon, Y., \& Park, N. (2011). Structural effects of cognitive and affective responses to web advertisements, website and brand attitudes, and purchase intentions: The case of casual-dining restaurants. International Journal of Hospitality Management, 30, 897-907

Kalaycı, Ş. (Ed.), (2006). SPSS uygulamalı çok değişkenli istatistik teknikleri (2. Baskı). Ankara: Asil Yayın Dağıtım.

Kandemir, H. (2016). Ulusal kültürün iş tatminine etkisinde, örgüt kültürünün aracılık etkisinin kısmi en küçük kareler yol analizi ile ölçülmesi. Akademik Sosyal Araştırmalar Dergisi (ASOS Journal), 4(32), 310-326.

Karagöz, Y. (2016). SPSS ve AMOS uygulamalı istatistiksel analizler. Ankara: Nobel Akademik Yayıncılık.

Kaya, F., \& Marangoz, M. (2014). Brand attitudes of entrepreneurs as a stakeholder towards a city. Procedia - Social and Behavioral Sciences, 150, 485-493.

Keller, K. L. (1993). Conceptualizing, measuring and managing customer- based brand equity. Journal of Marketing, 57(1), 1-22.

Ko, Y. J., Chang, Y., Park, C., \& Herbst, F. (2016). Determinants of consumer attitude toward corporate sponsors: A comparison between a profit and nonprofit sport event sponsorship. Journal of Consumer Behaviour, DOI: 10.1002/cb.1622.

Kotler, P., \& Keller, K.L. (2008). Marketing management (13th International Edition). London: Prentice Hall.

Kurtoğlu, R., \& Özbölük, T. (2016). Görsel iletişim çağında markaların emoji’ye adaptasyonu. Akademik Sosyal Araştırmalar Dergisi (ASOS Journal), 4(29), 144-155.

Kurtuluş, K. (1998). Pazarlama araştırmaları (6. Baskı). İstanbul: i.ü. İşletme Fakültesi Yayın No:274.

Lam, D., \& Dick, M. (2005). The effects of locus of control on word of mouth communication. Journal of Marketing Communications, 11(3), 215- 228.

Lee, Y. C., (2017). Effects of branded e-stickers on purchase intentions: The perspective of social capital theory. Telematics and Informatics, 34, 397-411.

Lee, C. (2003). The mercury project for instant messaging studies: How does internet messaging affect interaction between genders? https://web.stanford.edu/class/pwr3-25/group2/pdfs/IM_Genders.pdf

Lu, X., Ai, W., Liu, X., Li, Q., Wang, N., Huang, G., \& Qiaozhu, M. (2016). Learning from the ubiquitous language: An empirical analysis of emoji usage of smartphone users. UBICOMP'16, Proceedings of the 2016 ACM International Joint Conference on Pervasive and Ubiquitous Computing, September 12, Heidelberg, Germany.

Mangold, W. G., Miller, F., \& Brockway, G. R. (1999). Word of mouth communication in the service marketplace. Journal of Services Marketing, 13(1), 73-89.

Meredith, W. (1993). Measurement invariance, factor analysis and factorial invariance. Pyschometrika, 58, 525-543.

Meydan, C. H., \& Şeşen, H. (2011). Yapısal eşitlik modellemesi AMOS uygulamaları. Ankara: Detay Yayıncılık. 
Mitchell, A. A., \& Olson, J. C. (1981). Are product attribute beliefs the only mediator of advertising effects on brand attitude. Journal of Marketing Research, 18, 318-332.

Naylor, G., \& Kleiser, B.S. (2000). Negative versus positive word of mouth: An exception to the rule. Journal of Consumer Satisfaction, Dissatisfaction and Complaining Behavior, 13, 26-36.

Öztürk, S., \& Okumuş A. (2017). Çevrimiçi tabanlı perakende modellerinin tüketici güveni ve bağlılığı açısından kıyaslanması. Yönetim ve Ekonomi, 24(2), 543-561.

Öztürk, M. C., \& Savaş, A. T. (2014). Sosyal amaca yönelik pazarlama reklamlarının markaya yönelik tutum ve satın alma niyetine etkisi: Anadolu üniversitesi öğretim elemanlarına yönelik bir uygulama. Journal of Yasar University, 9(35), 6109-6128.

Park, J., Baek, Y. M., and Cha, M. (2014). Cross-cultural comparison of nonverbal cues in emoticons on Twitter: Evidence from big data analysis. Journal of Communication, 64(2), 333-354.

Phelps, J. E., \& Hoy, M. G. (1996). The ad-ab-pi relationship in children: The impact of brand familiarity and measurement timing, Psychology \& Marketing, 13(1), 77-105.

Pitta, D. A., \& Fowler, D. (2005). Online consumer communities and their value to new product developers. Journal of Product \& Brand Management, 14(5), 283-291.

Qiu, L., Wang, W., Pang, J., \& Jiang, Z. J. (2016). The persuasive impact of emoticons in online word-of-mouth communication. PACIS 2016 Proceedings.

Schiffman, L. G., \& Kanuk, L. L. (1995). Consumer behavior (9th Ed.). Upper Saddle River, NJ: Prentice Hall

Sernovitz, A. (2006). Word of mouth marketing: How smart companies get people talking. Kaplan Publishing.

Silverman, G. (2001). The secrets of word of mouth marketing, New York: American Management Assocation.

Spears, N., Singh, S. (2004). Measuring attitude toward the brand and purchase intentions. Journal of Current Issues \& Research in Advertising, 26(29), 53-66.

Stark, L., \& Crawford, K. (2015). The conservatism of emoji: Work, affect and communication. Social Media + Society, July- December, 1-11.

Stokes, D., \& Lomax, W. (2002), Taking control of word of mouth marketing: The Case of an entrepreneurial hotelier. Journal of Business and Enterprise Development, 9(4), 349-357.

Sundaram, D. S., Mitra, K., \& Webster, C. (1998). Word-of-mouth communications: A motivational analysis. In NA Advances in Consumer Research Vol.25, eds. Joseph W. Alba \& J. Wesley Hutchinson, Provo, UT : Association for Consumer Research, 527-531.

Sütütemiz, N. (2005). Müşteri sadakati belirleyicileri ve modellerinin karşılaştırılması: Bankacılık ve sağlık sektöründe bir araştırma. Sakarya Üniversitesi Sosyal Bilimler Enstitüsü Yayınlanmamış Doktora Tezi, Sakarya.

Swanson, S.R., \& Kelley, S.W. (2001), Service recovery attributions and word-of-mouth intentions. European Journal of Marketing, 35(1/2), 194-211.

Tabachnick, B. G., \& Fidell, L. S. (2013). Using Multivariate Statistics (Sixth edition). Boston: Pearson:

Ursavaş, Ö.F., Şahin, S., \& Mcllroy D. (2014). Technology acceptance measure for teachers: T-Tam, Eğitimde Kuram ve Uygulama, 10(4), 885-917.

Uztuğ, F. (2003). Markan kadar konuş. İstanbul: Mediacat Yayınları.

Walther, J. B., \& D’Addario, K. P. (2001). the impacts of emoticons on message interpretation in computer-mediated communication. Social Science Computer Review, 19(3), 324-347.

Wolf, A. (2000). Emotional expression online: Gender differences in emoticon use. CyberPsychology \& Behavior, 3(5), 827-833.

Wu, P. C. S., \& Wang, Y.C. (2010). The influences of electronic word-of-mouth message appeal and message source credibility on brand attitude. Asia Pacific Journal of Marketing and Logistics, 23(4), 448-472.

Yakın, V., \& Eru, O. (2017). An application to determine the efficacy of emoji use on social marketing Ads. International Journal of Social Sciences and Education Research, 3(1), 230-240.

Yıldız E., \& Koç, M.E., (2017). Marka mirası ve marka güveninin satın alma niyeti, müşteri tatmini ve marka sadakati üzerindeki etkileri. Dumlupınar Üniversitesi Sosyal Bilimler Dergisi Pazarlama Kongresi Özel Sayısı, Mayıs 2017, 86-104. 
This Page Intentionally Left Blank 